Environment, Biodiversity \& Soil Security
(EBSS)

\title{
Combined Application of various Sources of Organic Fertilizers with Biofertilizers for Improvement Potato Productivity and Soil Fertility Status
}

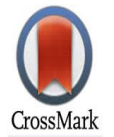

\section{El-Saied R.M. and Basma R.A. Rashwan}

Plant Nutrition Department, Soils, Water and Environment Research Institute, Agriculture Research Center, Giza, Egypt.

\begin{abstract}
$\mathbf{A}$
FIELD experiments were carried out during two successive seasons 2019 and 2020 in a private farm at Belqas district, Al-Daqahlia Governorate, Egypt to assay the effect of various sources of organic fertilizers (farmyard manure, compost, chicken manure and spent coffee ground) added either solely or combination with biofertilizers (N-fixers and PKdissolving bacteria) on the growth performance and productivity of potato plants. Results showed that the soil amended with chicken manure $\left(24.7 \mathrm{~m}^{3} \mathrm{ha}^{-1}\right)$ and inoculated by dual biofertilizers i.e. Paenibacillus polymyxa as nitrogen fixing bacteria and Enterobacter cloacae as phosphate and potassium solubilizing bacteria thatintroduced as talc-based formulation containing mixed strains,significantly enhanced remaining nutrientsin the soil post-harvest; Moreover, densities of bacterial population at 90 days'- time interval significantly increased. Also, the highest vegetative growth, yield attributes and tuber quality were recorded for the same treatment. On other hand, this treatment recorded the lowest nitrate content for both seasons. It is worth mentioning that soil amended with spent coffee grounds $\left(27.17 \mathrm{~m}^{3} \mathrm{ha}^{-1}\right)$ with bacterial inoculation has a positive effect onimproving soil fertility and potato productivity.
\end{abstract}

Keywords: Potato; farmyard manure; compost; Chicken manure; spent Coffee ground and biofertilization.

\section{Introduction}

Potato (Solanumtuberosum L.) is one of most important solanaceous vegetable crops for local consumption and exportation, occupied the fourth number after rice, wheat, and maize in production size (Walker et al., 1999). Potato iseconomical food which rich with starch, vitamin C\&B, minerals and essential amino acids (Khurana and Naik2003). Data obtained from the Egyptian agricultural quarantine statistics, Ministry of Agriculture and Land Reclamation, Egypt, revealed that the cultivated area of potato in 2019/2020 were about 192.31ha., which yielded about 5.8 million ton of tubers with an average of about 30.38 ton/ ha. Egypt imports 135.000 ton ofpotatofrom European Union as a seed to be cultivated. Egypt exported from it about 678.000 ton. Several reviews indicated that potatoes produced with organic fertilizers are healthier than potatoes produced using conventional methods. This is because organic potatoes contain fewer nitrates (Lairon, 2009) than potatoes produced with conventional practices. When using excessive of mineral fertilizers for long time periods, soil and pollution become potential threat less affecting negatively soil productivity and possessing serious health and environmental problems (Cockburn et al., 2011). For these reasons, several countries around the world changed their agricultural additives towards using safe organic and biological fertilizers (ElSayed et al., 2015).

Organic fertilization improves physical, chemical and biological properties of soil, adjusts

Corresponding author e-mail: dr.rehamelsaid@yahoo.com

Received 31/5/2021 ;Accepted 25/7/2021

DOI : $10.21608 /$ jenvbs.2021.78349.1138

(C)2021 National Information and Documentation Center (NIDOC) 
soil $\mathrm{pH}$ and increases solubility of macro and micro-nutrients in soil. Adding organic fertilizers can; enrich soil with nutrients needed for plant growth (Zaki et al. 2021) by increasing available phosphorus, potassium, calcium, and the other micro-elements contents, via its effect on soil $\mathrm{pH}$, encouraging proliferation of microorganisms, increasing microbial population and stimulating activities of microbial enzymes (Abou-Hussein et al., 2001). The use of various fresh or composted organic wastes has a role in potato production and soil fertility by improving organic matter, nutrient content, water hold capacity as well as aggregation of soil (Abdeldaym et al., 2018 and Shehata et al., 2019). Zaki et al. (2021) confirmed that application of organic additives has a positive effect on production and nutritional value of groundnut crop. Organic manures (such as compost and FYM) are vital organic resources and used for sustainable agriculture. Itis rich in nitrogen and other nutrients that can decrease the consumption of chemical fertilizer. These organic manures used for many centuries to increase soil fertility (Durzi, 2012). Hany and Darwesh, (2020) reported that inoculation by E. ludwigii (KP325139.1) combined with compost could compensate $50 \%$ of chemical fertilizer with significant increment in growth, yield and fruit quality of apple. As well, increasing soil content of most nutrients.

Using chicken manure as an organic fertilizer improves soil properties and crop production (Baddour et al., 2017). Chicken manure is a better amendment than many animal wastes because of its high concentration of macro nutrients (Dikinya and Mufwanzala, 2010). Spent coffee grounds (SCG), has a high humidity content $(80 \%-85 \%)$, fine particle size, organic load and acidity (Mussatto et al., 2011). The consumption of coffee produces high amounts of spent coffee grounds usually mixed with ordinary wastes which may cause environmental problems. On the other hand, this residue is rich in nitrogen, phosphorus and potassium (Mussatto et al., 2011 and Cruz et al., 2012), and may therefore be used in agriculture as fertilizer or probably as a soil conditioner (Kondamudi et al., 2008). Beside of being rich with bioactive compounds (e.g., phenolics, carotenoids, flavonoids, xanthines, diterpenes, melanoidins, vitamin precursors, etc.) (Stylianou et al., 2018).SCG (as organic fertilizer) versus NPK (as traditional fertilizer) increases the concentrations of several essential elements, which could reduce the use of

Env. Biodiv. Soil Security Vol. 5 (2021) chemical fertilizers, work on improvement of environmental sustainability. So,SCG as organic amendment give rise to the production of a food product that could be classified as ecological and, at the same time, improves its nutritional value (Cervera-Mata et al., 2019). References to its use as organic fertilizer in domestic cultures, especially in gardens, are common and there are numerous recommendations about its use as organic fertilizer in agriculture (Kasongo et al., 2011; Gomes et al., 2013 and Yamane et al., 2014). However, scientific evidence of its safety or even efficiency still unknown

Biofertilizers include efficient strains of nitrogen-fixing bacteria, phosphate and potassium solubilizing bacteria that increase absorption of available nutrients by plants (Shaaban et al., 2015), improve crop efficiency decrease pollution and achieve sustainable agriculture (Rahimi et al., 2019). Preparation of talc-based formulation as bacterial carrier was carried out to make the use of bacterial strains easier and also to improve their stability, vitality and durability in the rhizosphere. The bacterial survive in talc powder, this may be because talc had very low moisture equilibrium, relative hydrophobicity and chemical inertness; moreover, it reduces moisture absorption and prevents formation of hydrate bridges that give longer storage periods (Kumar, 2014 and Shaaban et al., 2015).

The integration effect of manure and soil microorganisms may improve soil aggregation, especially in light textured soils due to decomposition by soil microorganisms, as additional polysaccharides, act as glue between soil particles to increase soil pores to be suitable medium for plant growth due to efficiency of roots making easier absorption of nutrient and increasing nutrient uptake (Widowati et al., 2005). The application of biofertilizers with organic manure improves soil fertility, fertilizers efficiency and crop productivity (Kantikowati et al. 2019 and Elbaalawy et al. 2020)

Our objective for this study was to determine the effect of different organic fertilizers on soil fertility, quantity and quality of potato plants. In addition to, how biofertilization would impact potato production under different organic regimes.

\section{Material and Methods}

Experimental Site

A field experiment was carried out during two successive seasons (2019-2020) at Belqas 
district, Al-Daqahlia Governorate, Egypt, to study influence of various sources of organic fertilizers with or without biofertilization on soil fertility status as well as growth, yield and quality of potato plant.

\section{The experiment treatments}

The study experiments comprised of eleven treatments were allocated in a complete randomized block design with three replicates.

(1)-control $\quad(100 \% \quad \mathrm{NPK}), \quad(2)-50 \% \mathrm{NPK}$ Without organic addition, (3)- $50 \% \mathrm{NPK}+$ Farmyard manure (FYM), (4)-50\%NPK + Compost, (5)- 50\%NPK + Chicken manure, (6)$50 \%$ NPK + Spent Coffee Ground (SCG),(7)$50 \% \mathrm{NPK}+\mathrm{Biofertilizer}$ without organic addition,(8)-50\%NPK + FYM+biofertilizers,(9)$50 \%$ NPK + Compost+biofertilizers,(10)- 50\% NPK + Chicken manure+biofertilizers and(11)$50 \%$ NPK + SCG+biofertilizers. Soil sample was collected from the experimental field at the beginning of the experiment, air dried and sieved in a $2-\mathrm{mm}$ sieve. The chemical analysis was carried out according to the procedures outlined by Richards (1954), while mechanical and physical analysis was carried out according to Jackson (1958). Analyses were performed both prior to planting and after harvesting. The chemical, mechanical and physical properties of the collected soils are given in Table 1.

\section{The used fertilizers}

\section{Biofertilizer}

Paenibacilluspolymyxa and Enterobacter cloacae were used in the present experiment. E.cloacae LC07192 was provided from Microbiology Lab, Faculty of Science, Zagazig Univ., Egypt. While P.polymyxa was provided from the Microbiology Dept. Soils, Water and Environment Res. Inst., Agric. Res. Center, Giza, Egypt.
Preparation of talc-based formulation of
bacteria
Bacterial strain was inoculated into the nutrient broth medium by loopand incubated in a rotary shaker at $150 \mathrm{rpm}$ for $48 \mathrm{~h}$ at room temperature. One $\mathrm{kg}$ of talc powder was taken in a sterilized metal tray and its $\mathrm{pH}$ was adjusted to 7 by $\mathrm{CaCO}_{3}$ at the rate of $15 \mathrm{~g} \mathrm{~kg}^{-1}$. Ten grams of carboxymethyl cellulose (CMC) was added to 1 $\mathrm{kg}$ of talc and then autoclaved the mixture for 30 min on each of two consecutive days. The bacterial strains were grown and mixed equally (v/v), finally mixed with talc powder (Nandakumar et al., 2002). The $400 \mathrm{~mL}$ of $48 \mathrm{~h}$ grown bacterial suspension containing $21 \times 10^{7} \mathrm{CFU} \mathrm{ml}^{-1}$ for two strains were mixed with carrier-cellulose mixture under aseptic conditions. After drying (approximately to $35 \%$ moisture content) for overnight, it was packed in polypropylene bag sealed and stored at room temperature. At the time of application, the population of bacteria in the formulation was $13 \times 10^{7} \mathrm{CFU} \mathrm{g}^{-1}$ for two mixed strains of talc powder.

\section{Inoculation process}

Tubers of potato (Solanum tubersum L.); cv. spunta (imported from Holland) were used in the present investigation and obtained from Agric. Res. Center (ARC), Ministry of Agriculture and landreclamation. Potatotubers were cut (approximately $35 \mathrm{~g}$ pieces). Pieces of potato tuber were successfully washed with water and air dried then mixed with talc-based formulation by dual strains according to treatments.

\section{Organic Fertilizers}

Farmyard manure (FYM) and chicken manure was taken from a private station of animal production, while compost was taken from company for organic manures Egyptian Company for Solid Waste Recycling. El Minia Egypt (ECARU). The fresh spent coffee ground (SCG)

TABLE 1. Some physiochemical properties of the experimental soil at depth $(0-30 \mathrm{~cm})$ before plantation in 2019 and 2020 seasons.

\begin{tabular}{|c|c|c|c|c|c|c|c|c|c|c|c|}
\hline \multirow[t]{2}{*}{ Season } & \multicolumn{4}{|c|}{ Physical properties } & \multirow{2}{*}{$\begin{array}{c}\text { Organic } \\
\text { matter } \\
\left(\mathrm{g} \mathrm{kg}^{-1}\right)\end{array}$} & \multirow{2}{*}{$\begin{array}{c}E C \\
\mathrm{dSm}^{-1}\end{array}$} & \multirow{2}{*}{ pH } & \multirow{2}{*}{$\begin{array}{l}\text { SP } \\
(\%)\end{array}$} & \multicolumn{3}{|c|}{$\begin{array}{l}\text { Nutrient content } \\
\qquad\left(\mathrm{mgkg}^{-1}\right)\end{array}$} \\
\hline & Clay & Silt & Sand & Texture & & & & & $\mathbf{N}$ & $\mathbf{P}$ & $\mathbf{K}$ \\
\hline $1^{\text {st }}$ season & 29.9 & 36.9 & 33.2 & $\begin{array}{c}\text { Sand clay } \\
\text { loam }\end{array}$ & 9.3 & 1.89 & 7.88 & 53.5 & 27.7 & 5.07 & 231 \\
\hline $2^{\text {nd }}$ season & 29.2 & 37.3 & 33.5 & $\begin{array}{c}\text { Sand clay } \\
\text { loam }\end{array}$ & 9.8 & 1.86 & 7.85 & 53.5 & 27.2 & 5.12 & 224 \\
\hline
\end{tabular}


was collected from various coffee establishments in the Mansoura city, followed by filtration and air drying. Organic manures were added to the soil before cultivation at a rate of $(49.4,32.11$, 24.7 and $27.17 \mathrm{~m}^{3} \mathrm{ha}^{-1}$ ) for FYM, compost, chicken manure and SCG respectively. FYM was utilized at its recommended dose of $49.4 \mathrm{~m}^{3}$ ha ${ }^{1}$ and the equivalent amounts from compost, chicken manures and SCG were calculated according to their $\mathrm{N}$ content and weight of $1 \mathrm{~m}^{3}$ of each. $\left(1 \mathrm{~m}^{3}\right.$ FYM, compost, chicken manure and SCG weighed $700,780,575$ and $550 \mathrm{~kg}$ ) orderly. The chemical analyses of used organic manure are shown in Table 2 .

\section{Chemical Fertilizers}

$100 \%$ Recommended dose were applied at a

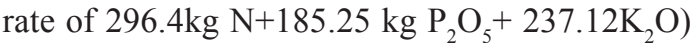
$\mathrm{ha}^{-1}$ to control treatment, on other hand, rest of treatments were treated with $50 \%$ NPK in form of ammonium sulphate $(20.5 \% \mathrm{~N})$, calcium super phosphate $\left(15.5 \% \mathrm{P}_{2} \mathrm{O}_{5}\right)$ and potassium sulphate $\left(48 \% \mathrm{~K}_{2} \mathrm{O}\right)$.

\section{Cultivation Process}

Cultivation process was performed in first week of January for two seasons. Each treatment was replicated three times; the plot area was 10.5 $\mathrm{m}^{2}$, which contained three rows, $5 \mathrm{~m}$ long and $0.7 \mathrm{~m}$ wide. Pieces of tubers were planted at 25 $\mathrm{cm}$ apart between each other, depth $(10-15 \mathrm{~cm})$ on one side of ridges. Other field practices for potato growing were followed according to the recommendation of the Ministry of Agriculture and Land Reclamation.

\section{Sampling and Determinations \\ Microbial count determination in soil}

The rhizosphere soil samples were collected at the initial (before treatment) and at different time intervals 30, 60 and 90 DAS (Days after sowing). Bacterial population count was performed by dissolving 10 gram of soil in Erlenmeyer flaskfilled with $90 \mathrm{ml}$ of $0.85 \%$ sterile $\mathrm{NaCl}$. Then put in a $120 \mathrm{rpm}$ shaker for 30 minutes to obtain $10^{-1}$ dilution. Serial dilutions were made up to $10^{-7}$. Then $1 \mathrm{ml}$. of each dilution was dropped in a sterile petri dish then respective media was poured over. Enumeration of total bacteria, nitrogen fixing bacteria, PSB (Phosphorous solubilizing bacteria), KSB (Potassium solubilizing bacteria) was done on nutrient agar medium (Difco Manual, 1974), Norris glucose nitrogen free medium (Lin et al., 2002), NBRIP medium (national botanical institute's phosphate growth medium, Nautiyal, 1999) and Alexandrov medium (Hu et al., 2006), respectively. The number of viable cells was measured by $\mathrm{CFU}$ (colony forming unit/ soil $(\mathrm{g})$.

Vegetative growth parameters

Samples were randomly taken from plots at 60 days after planting to determine vegetative growthparameters (plant height $(\mathrm{cm})$, number of branches and leaves/plant, fresh and dry weight of shoots and dry weight of shoots (g)/plant).

Tuber yield and its components

Number and weight of tubers/plant were determined. Weight yield/fed (ton) was calculated.

Determination of photosynthetic pigment content

Three plant samples were randomly taken from each plot for determination chlorophyll $\mathrm{a}$, chlorophyll $\mathrm{b}$ and carotenoid on the $4^{\text {th }}$ leaf from the plant apex. According to Metzner et al. (1965).

\section{Tuber Quality}

At harvest, fresh weight of tubers was taken from each plot to determine their contents of total carbohydrate, N, P, K, protein and nitrate. Carbohydrates were estimated according to anthrone method (Sadasivam and Manickam, 1996). The modified Micro-kjeldahl apparatus was employed for total N-determination as described by Jones et al. (1991). Protein content was calculated by multiplying $\mathrm{N}$ content by 6.25 (Ranganna, 1977). Total phosphorus content was estimatedspectrophotomitrically by model no. UV2100 S/N: BH 16041603003. Powersource AC220V/50Hz. FUSE: $250 \mathrm{~V} / 3.15 \mathrm{~A}$ FASTACTING. according to Peters et al.(2003). Total potassium content was determined by photometerically by JENWAY PFP7 model according to Peters et al. (2003). Nitrate content was determined according to Cheng and Tsang (1998).

\section{Statistical Analysis}

The eleven treatments of two seasons (2019-2020) each were arranged in a complete randomized block design with three replicates. Data were analyzed with statistical analysis software; CoState (2005). All multiple comparisons were first subjected to analysis of variance (ANOVA). Comparisons among means were made using Duncan's multiple range test at a $\mathrm{P}$ level of 0.05 . 
TABLE 2. Chemical analysis of the organic manures used.

\begin{tabular}{ccccc}
\hline Organic manure & FYM & Compost & Chicken manure & SCG \\
\hline Nitrogen (\%) & $\mathbf{1 . 4 5}$ & $\mathbf{1 . 7 4}$ & $\mathbf{2 . 9 3}$ & $\mathbf{2 . 8 0}$ \\
Phosphorous(\%) & $\mathbf{1 . 0 7}$ & $\mathbf{1 . 6 1}$ & $\mathbf{2 . 1 1}$ & $\mathbf{1 . 8 1}$ \\
Potassium(\%) & 0.89 & 1.14 & 1.73 & 1.70 \\
Organic matter(\%) & 40.17 & 50.44 & 62.33 & 56.50 \\
Fe(mg $/ \mathrm{kg})$ & 27.55 & 48.65 & 57.00 & 51.50 \\
Cu(mg/kg) & 17.44 & 22.65 & 30.00 & 17.00 \\
Zn(mg/kg) & 11.55 & 13.54 & 21.00 & 10.50 \\
$(\mathrm{C} / \mathrm{N}$ ratio) & 20.10 & 18.75 & 15.71 & 16.17 \\
\hline
\end{tabular}

FYM= Farmyardmanure, $\mathrm{SCG}=$ Spent Coffee Ground

\section{Results and Discussion}

Remaining nutrients in the soil postharvest

Data presented in (Table 3), revealed that the available nutrients contents in the rhizosphere after harvesting potato plants, increased significantly due to the application of organic amendments and./or inoculation by dual bacterial strains i.e., Nitrogen fixing bacteria (Paenibacillus polymyxa), phosphate and potassium solubilizing bacteria (Enterobacter cloacae). In this concern, the highest increases in available nutrients were attained for the application of chicken manure in presence of the biofertilizers. For nitrogen content increased by (3.10 and $3.23 \%$ ), phosphorous by ( 8.33 and $8.33 \%)$, potassium by (6.49 and $6.55 \%$ ) and OM by $(24.49$ and $32.26 \%)$ in the $1^{\text {st }}$ and $2^{\text {nd }}$ seasons, respectively comparing with control (100\%NPK). While, $\mathrm{pH}$ values were slightly decreased to $\mathrm{pH}$ in soil ( 7.81 for $1^{\text {st }}$ season and 7.78 for $2^{\text {nd }}$ season). These results are in harmony with those outlined by Abou-Zeid and Bakry (2011) and AbdEl-Nabi et al. (2016) on potato. Integrated SCG with dual strains enhanced remaining nutrient compared with control for $\mathrm{N}$ content increased by (2.41 and $2.54 \%), \mathrm{P}$ by (5.83 and $5.00 \%), \mathrm{K}$ by (4.76 and $4.80), \mathrm{OM}$ by (17.35 and $24.73 \%)$ in the $1^{\text {st }}$ and $2^{\text {nd }}$ seasons, respectively. Adding organic manure as a soil amendment was more benefit for soil fertility status, due to its contents of macro- $(\mathrm{N}$, $\mathrm{P}$ and $\mathrm{K}$ ) and micronutrients ( $\mathrm{Fe}, \mathrm{Zn}$ and $\mathrm{Cu}$ ). Also, the beneficial effect of organic manures, on an increase of available nutrient contents in the soil may be attributed to their slow release of these fertilizers during the mineralization and decomposition processes as well as minimizing their possible loses by leaching (Mohammed, 2004 and Rashwan et al., 2018).

\section{Microbial population in the rhizosphere of potato} plants

Data in Fig. (1) illustrated the periodical changes of total bacteria, nitrogen fixing bacteria, phosphate and potassium dissolving bacteria within the rhizosphere of potato plants. Probably, organic fertilization encourages proliferation of soil microorganisms (Bakry et al., 2009). Concerning inoculation treatments, it was observed that microbial densities of the above mentioned microbial groups gradually increased with increasing the incubation period to reach their maximum values at 90 days. This is probably because these amendments influence positively plant root exudates and nutrients that stimulate microbial communities. These results are in accordance with Abdel-Magid et al. (1996) who reported that the total CFU counts of soil microorganisms' increase with addition organic fertilizers. On other hand, un-inoculated treatments reach their maximum values at 60 days then the population decreased thereafter and this may be attributed to the decrease in optimum temperature during winter season (Kaur et al., 2017) and/or decrease in the easily oxidized organic fractions of the organic amendments (Abdelhafez et al., 2018; Elcossy et al., 2020 and Mohamed et al., 2021). Rhizosphere of potato 
plants inoculated with biofertilizersin presence of organic fertilizers gave higher densities of bacteria population than the corresponding ones recorded in presence of organic fertilizers solely. It is well known that E. cloacae and $P$. polymyxa not only provide plants with nitrogen but also produce a variety of growth-promoting substances (Attar et al., 2015 and Widowati et al., 2019) and root exudates which in turn stimulate microbial activities. The results showed that the introduced inoculum able to survive and colonize the root zone of potato plants (Abdel-Ati et al., 1996 and Saleh et al., 1998). The obtained results indicated that microbial population was affected by biofertilizer inoculation and the stage of plant growth.Increasing bacterial population is due to establishment of bacterial population with nutrients availability (Houlden et al., 2008).
The interaction between different types of organic treatments and biofertilizers showed that rhizosphere of potato plants amended with chicken manure and received biofertilizers gave the highest densities of bacterial population at 90 days' time interval $\left(97.19 \times 10^{7}, 24.00 \times 10^{5}\right.$, $90.16 \times 10^{4}$ and $\left.50.07 \times 10^{4}\right) \mathrm{CFU} \mathrm{g^{-1 }}$ soil for total bacteria, nitrogen fixing bacteria, Phosphorous solubilizing bacteria (PSB) and potassium solubilizing bacteria (KSB) respectively compared with other treatments. Similar results were recorded by Mandic et al. (2011), AbouZeid and Bakry (2011) on potato and Gao et al. (2020) on maize. The positive action of chicken manure may be due to the beneficial effect on microflora and phytohormones (Mandal et al., 2007 and Zhong et al., 2010). The increase in

TABLE 3. Influence of application various sources of organic fertilizers either solely or combined with biofertilizers on remaining nutrients $\left(\mathrm{mg} \mathrm{kg}^{-1}\right)$, organic matter percentage and $\mathrm{pH}$ value in the soil postharvest during the two seasons 2019-2020.

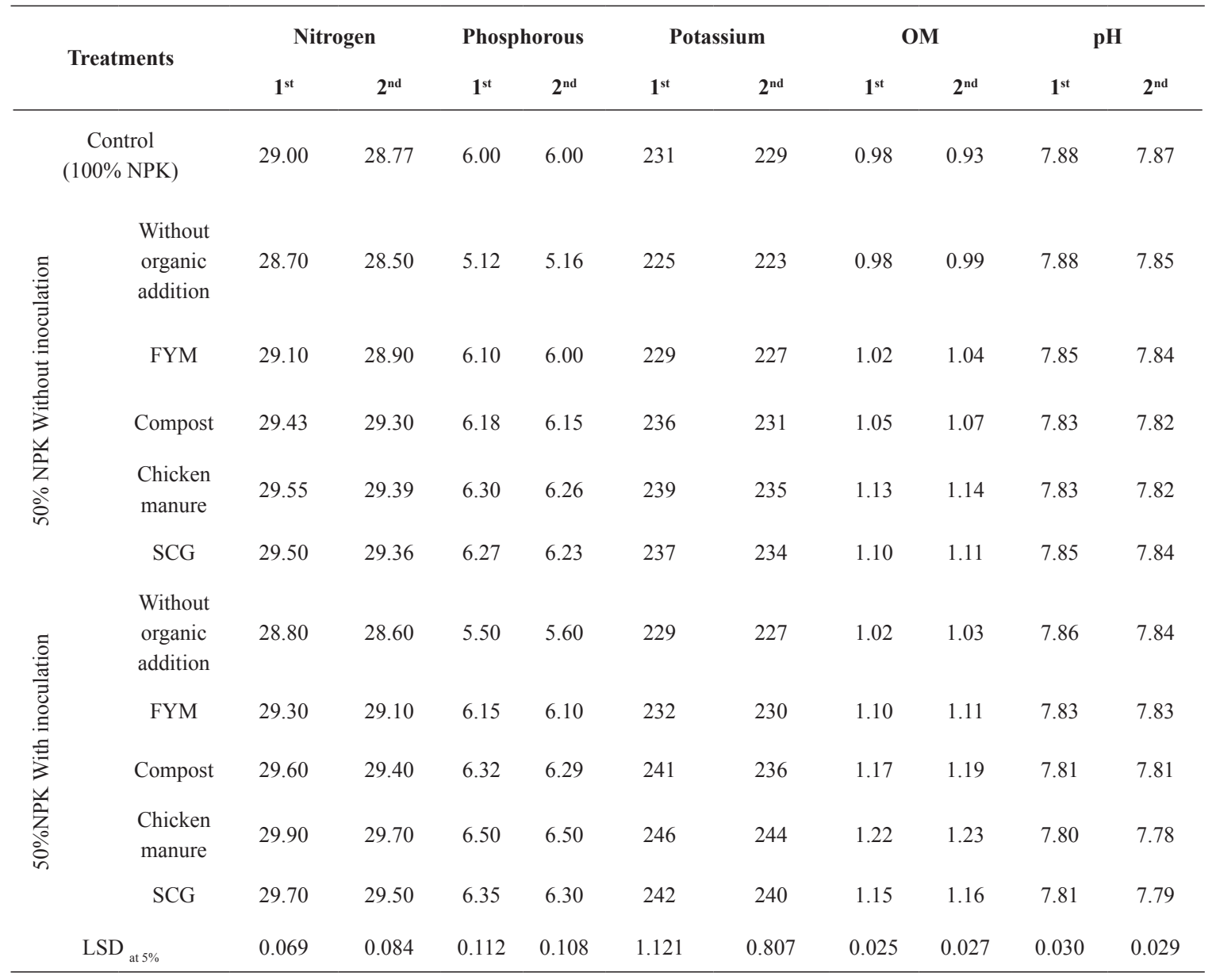

FYM= Farmyardmanure, $\mathrm{SCG}=$ Spent Coffee Ground, $\mathrm{OM}=$ Organic matte

Env. Biodiv. Soil Security Vol. 5 (2021) 
bacterial population from 30 DAS to 90 DAS may be due to talc-based formulation as bacterial carrier which makes the use of bacterial strains easier and improve their stability, durability and vitality in the rhizosphere was observed within
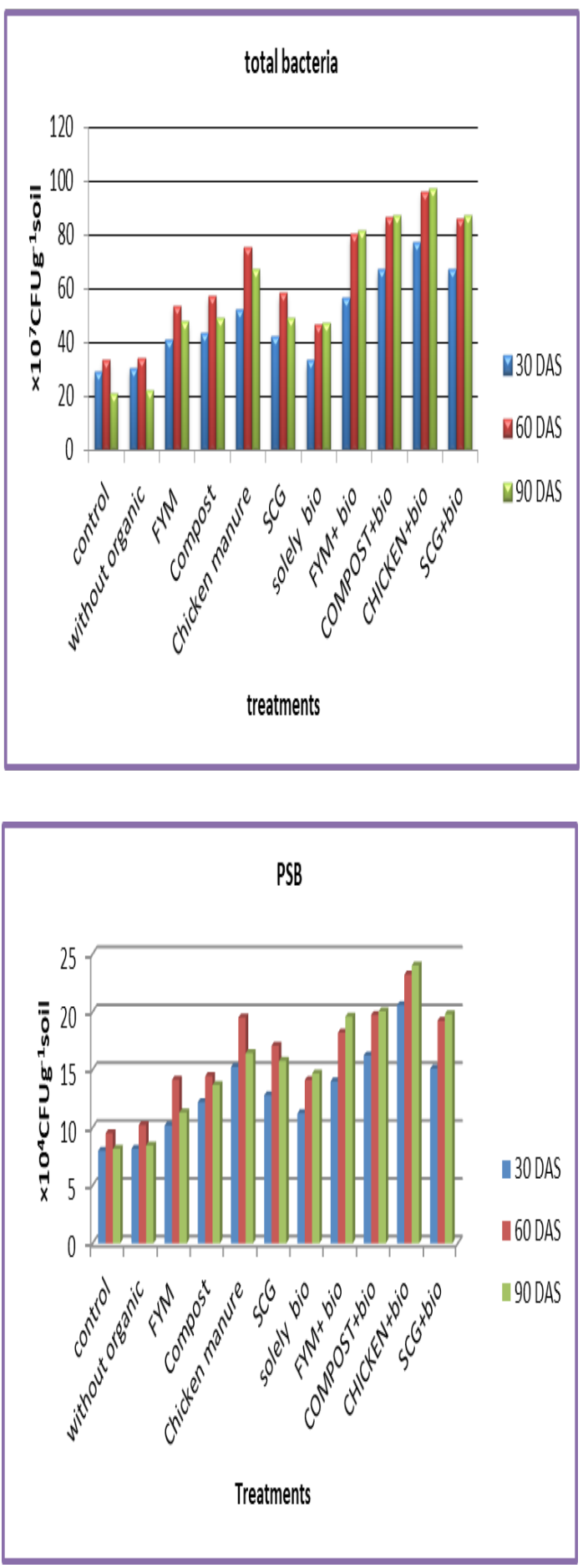

the population (Jambhulkar and Sharma, 2014; Kumar, 2014 and Shaaban et al., 2015). Moreover, the shelf life of bacteria varies depending upon bacterial genera, carriers and their particle size
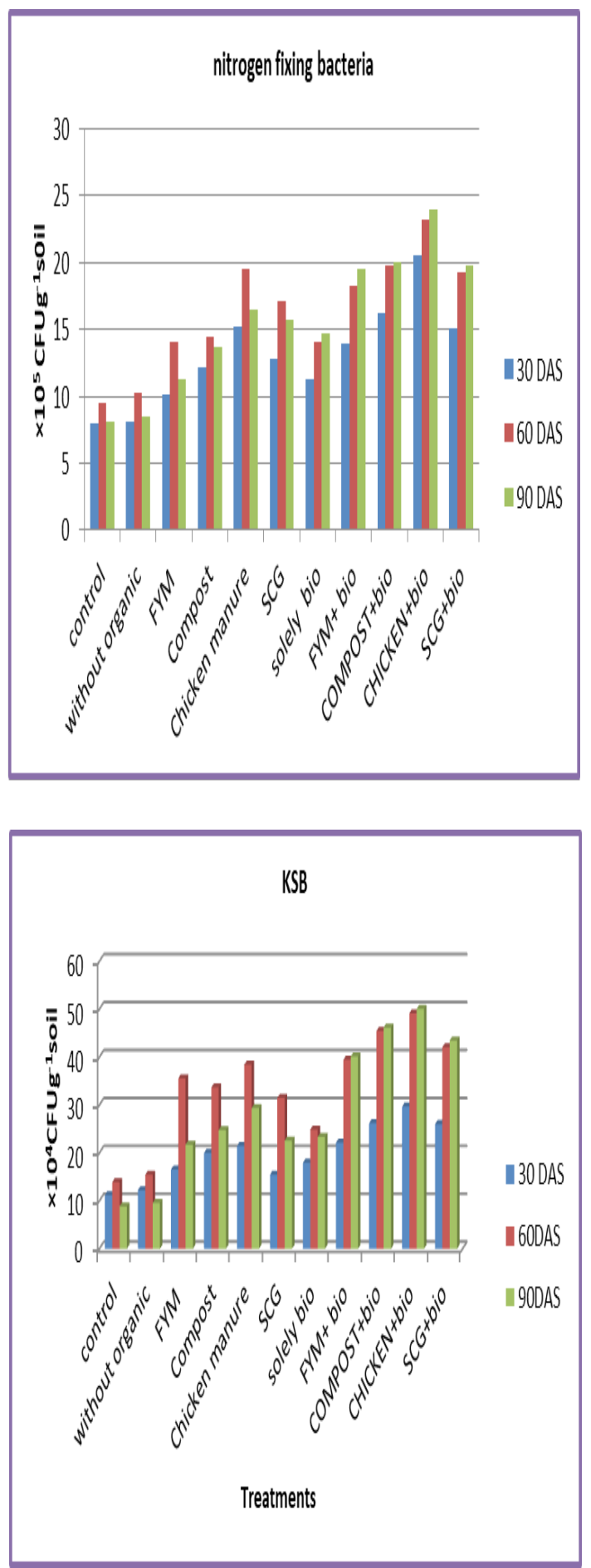

Fig. 1. Influence of application various sources of organic fertilizers either solely or combined with biofertilizers on bacterial population in the rhizosphere zone. (Average of the two seasons) . 
(Bora et al., 2004 and Sivakumar et al., 2012).

Vegetative growth parameters

Data presented in (Table 4) showed that growth parameters of potato plant at the vegetative growth stage (60 days after planting) recorded in both seasons of 2019 and 2020 as affected by application of different organic fertilizers (farmyard manure, compost, chicken manure and spent coffee ground) either solely or in combination with biofertilizers (P. polymyxaand E. cloacae). With respect to integration chicken manure and biofertilizers, this treatment significantly enhanced growth parameters. Plant height recorded increasing in height comparing with control by (1.07 and $3.76 \%$ ) in $1^{\text {st }}$ and $2^{\text {nd }}$ seasons respectively. Also, it significantly increased the number of branches by $(8.33$ and $8.00 \%)$, leaves number by $(1.79$ and $4.69 \%$ ), fresh weight by (1.28 and $2.79 \%)$ and dry weight by (3.91 and $4.52 \%$ ) for $1^{\text {st }}$ and $2^{\text {nd }}$ seasons respectively. These results were in line with those obtained by Kantikowati et al. (2019) and Zaki et al. (2019).

The positive action of chicken manure on vegetative growth may be due to the fact that it contains a large percentage of organic matter besides being rich in macro and micronutrients that improve plant vegetative growth (Bhangoo et al., 1988). On the other hand, bacterial inoculation probably enhanced plant growth through the production of hormones, especially IAA (Sheng and Huang, 2001) which increased cell division and elongation. E. cloacae is not only a $\mathrm{N}$ fixer (Mauricio et al., 2009) but also has the capability of phosphate and potassium solubilizing ability (El-Saied et al., 2020). Phosphorus and nitrogen have important roles in the molecular structure of nucleic acids resulting in increased protein synthesis and protoplasm formation (Mengel and Kirkby, 1987 and El-Shanshoury, 1995).

\section{Tuber yield and its components}

Effects of different types of organic fertilizers added as either solely or combination with biofertilizers on yield of potato during two successive seasons were represented in (Table $5)$. As for the synergetic effect of various organic fertilizers and biofertilizers (P. polymyxa and $E$. cloacae) on yield parameters, values revealed that chicken manure combined with inoculated bacteria recorded enhancing in number of tubers/ plant by (5.26 and 3.00\%); weight of yield/plant by (4.35 and $4.43 \%$ ); and this consequently increased weight yield/ha. by (4.34 and 4.36\%) for $1^{\text {st }}$ and $2^{\text {nd }}$ seasons respectively comparing with those received recommended dose of NPK. These results were consistent with the findings of El-Sayed et al. (2014), Kantikowati et al. (2019) and Zaki et al. (2019). The positive effect of chicken manure could be due to a higher content of organic matter and nitrogen as well as some nutrients which led to significant improvement in the nutritional status of potato and this, in turn, was reflected on potato yield (Kannaiyan, 2002). Also, solubilization of P and $\mathrm{K}$ in soil by E.cloacae probably took place and this consequently increased $\mathrm{P}$ and $\mathrm{K}$ availability in soil (Park et al., 2003). Furthermore, nitrogen fixation increased by $P$. polymyxa affecting positively vegetative growth and yield of potato plants (Premsekhar and Rajashree, 2009). It is worth to mention that plots received SCG combined with inoculated bacteria gave positive effects on yield attributes. This improvement could be related to the richness of fresh SCG in mineral nutrients, especially $\mathrm{N}$ (Table 2) (Gomes et al., 2013).

\section{Photosynthetic pigments content}

Regarding to (Table 6) represented application of different types of organic fertilizers in conjunction with or without biofertilizers on photosynthetic pigments during two seasons. Results showed that, soil amended with chicken manure and biofertilizers ( $P$. polymyxa and E. cloacae) exhibited significantly higher contents of chlorophyll a, chlorophyll b and carotenoid contents by $(11.43$ and $5.16 \%, 26.32$ and $12.60 \% \& 18.97$ and $11.17 \%$ ), respectively for $1^{\text {st }}$ and $2^{\text {nd }}$ seasons comparing with control (100\% NPK). These results have been matched with Abd El-Nabi et al. (2016) and Singh et al. (2018). While, combining SCG with bacteria inoculation increased chl a content by (5.71 and $4.39 \%$ ), chl b by (19.21 and $10.04 \%)$ and carotenoid by (11.03 and $6.33 \%)$ for $1^{\text {st }}$ and $2^{\text {nd }}$ seasons, respectively comparing with $100 \% \mathrm{NPK}$. The improvement in chlorophyll contents may be a result of promotion of cytokinins secreted by $\mathrm{N}_{2}$ fixatives to delay senescence of plant tissues through their effect in reducing chlorophyll loss (Gaballah, 1995). Also, phosphate solubilizing bacteria stimulate chlorophyll synthesis through stimulation of pyridoxal enzyme formation that plays an important role in amino levulinic acid synthetase as a primary compound in chlorophyll synthesis (Al-Fraihat et al., 2011 and Hassan and 
TABLE 4. Influence of application various sources of organic fertilizers either solely or combined with biofertilizers on the vegetative growth parameters of potato plants during the two seasons 2019-2020.

\begin{tabular}{|c|c|c|c|c|c|c|c|c|c|c|c|}
\hline \multirow{2}{*}{\multicolumn{2}{|c|}{ Treatments }} & \multicolumn{2}{|c|}{$\begin{array}{l}\text { Plant height } \\
(\mathrm{cm})\end{array}$} & \multicolumn{2}{|c|}{ No. of Branch } & \multicolumn{2}{|c|}{ No. of leaves } & \multicolumn{2}{|c|}{$\begin{array}{l}\text { F. wtshoot } \\
\text { (g/plant) }\end{array}$} & \multicolumn{2}{|c|}{$\begin{array}{l}\text { D. wt shoot (g/ } \\
\text { plant) }\end{array}$} \\
\hline & & $1^{\text {st }}$ & $2^{\text {nd }}$ & $1^{\text {st }}$ & $2^{\text {nd }}$ & $1^{\text {st }}$ & $2^{\text {nd }}$ & $1^{\text {st }}$ & $2^{\text {nd }}$ & $1^{\text {st }}$ & $2^{\text {nd }}$ \\
\hline \multirow{5}{*}{ 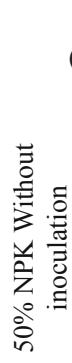 } & $\begin{array}{l}\text { rol } \\
\text { NPK) }\end{array}$ & 93.50 & 106.50 & 12.00 & 12.50 & 56.00 & 64.00 & 78.00 & 80.75 & 20.73 & 22.12 \\
\hline & $\begin{array}{l}\text { Without } \\
\text { organic }\end{array}$ & 64.75 & 70.00 & 5.50 & 6.00 & 35.50 & 39.00 & 39.19 & 43.27 & 10.05 & 10.18 \\
\hline & FYM & 82.50 & 81.50 & 8.00 & 8.00 & 43.00 & 48.50 & 53.37 & 57.54 & 14.50 & 15.12 \\
\hline & Compost & 87.00 & 88.75 & 9.50 & 9.45 & 45.75 & 51.00 & 61.44 & 63.50 & 15.57 & 15.79 \\
\hline & $\begin{array}{l}\text { Chicken } \\
\text { manure }\end{array}$ & 90.50 & 93.80 & 10.00 & 11.50 & 48.00 & 54.70 & 68.80 & 68.77 & 17.00 & 16.83 \\
\hline \multirow{4}{*}{ 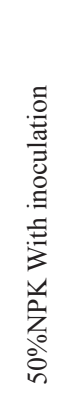 } & FYM & 88.90 & 91.00 & 10.80 & 12.00 & 46.50 & 55.50 & 68.91 & 70.18 & 17.08 & 17.50 \\
\hline & Compost & 90.75 & 97.50 & 10.80 & 12.00 & 53.00 & 58.75 & 73.50 & 77.14 & 19.21 & 20.31 \\
\hline & $\begin{array}{l}\text { Chicken } \\
\text { manure }\end{array}$ & 94.50 & 110.50 & 13.00 & 13.50 & 57.00 & 67.00 & 79.00 & 83.00 & 21.54 & 23.12 \\
\hline & SCG & 92.75 & 108.00 & 11.50 & 13.00 & 53.50 & 63.50 & 78.17 & 81.90 & 21.27 & 22.81 \\
\hline \multicolumn{2}{|c|}{$\mathrm{LSD}_{\text {at } 5 \%}$} & 1.469 & 1.578 & 0.577 & 0.667 & 0.769 & 1.095 & 0.644 & 0.550 & 0.450 & 0.402 \\
\hline
\end{tabular}

FYM $=$ Farmyard manure,SCG $=$ Spent Coffee Ground

TABLE 5. Influence of application various sources of organic fertilizers either solely or combined with biofertilizers on tuber yield and its components of potato plants during the two seasons 2019-2020.

\begin{tabular}{|c|c|c|c|c|c|c|c|}
\hline & \multirow[t]{2}{*}{ Treatments } & \multicolumn{2}{|c|}{$\begin{array}{c}\text { Number of tubers/ } \\
\text { (plant) }\end{array}$} & \multicolumn{2}{|c|}{$\begin{array}{l}\text { Weight tubers/ } \\
\text { plant (g) }\end{array}$} & \multicolumn{2}{|c|}{$\begin{array}{c}\text { Weight yield/ha. } \\
\text { (ton) }\end{array}$} \\
\hline & & $1^{\text {st }}$ & $2^{\text {nd }}$ & $1^{\text {st }}$ & $2^{\text {nd }}$ & $1^{\text {st }}$ & $2^{\text {nd }}$ \\
\hline Control & $(100 \%$ NPK) & 4.75 & 5.00 & 575.00 & 587.50 & 34.09 & 34.83 \\
\hline \multirow{5}{*}{ 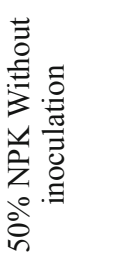 } & Without organic & 3.15 & 3.35 & 441.00 & 459.00 & 26.13 & 27.22 \\
\hline & FYM & 3.50 & 3.65 & 469.00 & 487.00 & 27.81 & 28.87 \\
\hline & Compost & 4.00 & 4.00 & 483.50 & 495.00 & 28.65 & 29.34 \\
\hline & Chicken manure & 4.15 & 4.20 & 505.75 & 510.75 & 29.99 & 30.28 \\
\hline & SCG & 4.00 & 4.15 & 488.85 & 500.00 & 28.97 & 29.64 \\
\hline \multirow{5}{*}{ 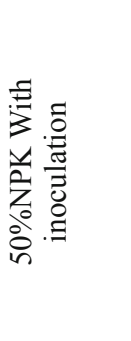 } & $\begin{array}{l}\text { Without organic } \\
\text { addition }\end{array}$ & 3.25 & 3.50 & 469.00 & 471.00 & 27.81 & 27.91 \\
\hline & FYM & 4.50 & 4.65 & 498.00 & 493.50 & 29.52 & 29.24 \\
\hline & Compost & 4.75 & 4.75 & 525.50 & 537.50 & 31.15 & 31.86 \\
\hline & Chicken manure & 5.00 & 5.15 & 600.00 & 613.50 & 35.57 & 36.35 \\
\hline & SCG & 4.80 & 5.00 & 560.00 & 571.75 & 33.19 & 33.89 \\
\hline \multicolumn{2}{|r|}{$\mathrm{LSD}_{\text {at } 5 \%}$} & 0.0971 & 0.118 & 5.187 & 7.268 & 0.269 & 0.405 \\
\hline
\end{tabular}


TABLE 6. Influence of application various sources of organic fertilizers either solely or combined with biofertilizers on photosynthetic pigments during the two seasons 2019-2020.

\begin{tabular}{|c|c|c|c|c|c|c|c|c|c|}
\hline \multirow{2}{*}{\multicolumn{2}{|c|}{ Treatments }} & \multicolumn{2}{|c|}{$\begin{array}{l}\text { Chl a } \\
(\mathrm{mg} / \mathrm{g})\end{array}$} & \multicolumn{2}{|c|}{$\begin{array}{l}\text { Chl b } \\
(\mathrm{mg} / \mathrm{g})\end{array}$} & \multicolumn{2}{|c|}{$\begin{array}{c}\text { Total chlorophyll } \\
(\mathrm{mg} / \mathrm{g})\end{array}$} & \multicolumn{2}{|c|}{$\begin{array}{c}\text { Cartenoid } \\
(\mathrm{mg} / \mathrm{g})\end{array}$} \\
\hline & & $1^{\text {st }}$ & $2^{\text {nd }}$ & $1^{\text {st }}$ & $2^{\text {nd }}$ & $1^{\text {st }}$ & $2^{\text {nd }}$ & $1^{\text {st }}$ & $2^{\text {nd }}$ \\
\hline \multicolumn{2}{|c|}{$\begin{array}{l}\text { Control } \\
\text { (100NPK) }\end{array}$} & 0.805 & 0.775 & 0.380 & 0.365 & 1.185 & 1.14 & 0.580 & 0.537 \\
\hline \multirow{4}{*}{ 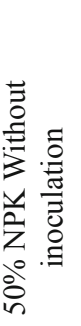 } & $\begin{array}{l}\text { Without } \\
\text { organic }\end{array}$ & 0.521 & 0.449 & 0.192 & 0.187 & 0.713 & 0.636 & 0.310 & 0.277 \\
\hline & FYM & 0.602 & 0.537 & 0.254 & 0.271 & 0.856 & 0.808 & 0.361 & 0.319 \\
\hline & Compost & 0.641 & 0.582 & 0.307 & 0.288 & 0.948 & 0.870 & 0.418 & 0.371 \\
\hline & $\begin{array}{l}\text { Chicken } \\
\text { manure }\end{array}$ & 0.711 & 0.673 & 0.372 & 0.331 & 1.083 & 1.004 & 0.473 & 0.436 \\
\hline \multirow{6}{*}{ 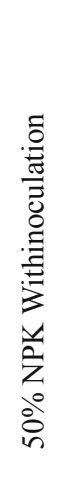 } & SCG & 0.685 & 0.641 & 0.338 & 0.305 & 1.023 & 0.946 & 0.441 & 0.409 \\
\hline & $\begin{array}{l}\text { Without } \\
\text { organic } \\
\text { addition }\end{array}$ & 0.571 & 0.482 & 0.216 & 0.191 & 0.787 & 0.673 & 0.327 & 0.283 \\
\hline & FYM & 0.736 & 0.703 & 0.361 & 0.330 & 1.097 & 1.033 & 0.509 & 0.473 \\
\hline & Compost & 0.821 & 0.778 & 0.404 & 0.371 & 1.225 & 1.149 & 0.583 & 0.520 \\
\hline & $\begin{array}{l}\text { Chicken } \\
\text { manure }\end{array}$ & 0.897 & 0.815 & 0.480 & 0.411 & 1.377 & 1.226 & 0.690 & 0.597 \\
\hline & SCG & 0.851 & 0.809 & 0.453 & 0.393 & 1.304 & 1.202 & 0.644 & 0.571 \\
\hline \multicolumn{2}{|c|}{$\mathrm{LSD}_{\text {at } 5 \%}$} & 0.011 & 0.014 & 0.016 & 0.016 & 0.020 & 0.019 & 0.015 & 0.015 \\
\hline
\end{tabular}

$\mathrm{Chl} \mathrm{a}=$ chlorophyll $\mathrm{a}, \mathrm{Chl} \mathrm{b}=$ chlorophyll b, FYM= Farmyard manure, $\mathrm{SCG}=$ Spent Coffee Ground

Ali, 2013).

The quality of tubers

Results in (Table 7) showed the effect of different types of organic fertilizers with or without biofertilizers ( $P$. polymyxa and $E$. cloacae) on potato tubers quality. Plots that received chicken manure in combination with biofertilizers exhibited significantly higher chemical constituents in potato tubers than those received the recommended NPK doses by $(3.03$ and $3.40 \%, 5.63$ and $10.96 \%, 4.04$ and $9.72 \% \&$ 3.05 and $3.40 \%$ ) for $\mathrm{N}, \mathrm{P}, \mathrm{K}$ and protein content in $1^{\text {st }}$ and $2^{\text {nd }}$ seasons, respectively, as well as enhanced total carbohydrate by (3.54 and 4.60\%). Similar findings were recorded on peache (Fayed et al., 2019) and potato (Zaki et al., 2019). Increase in nutrient concentration as a result of biofertilizers application may be due application of free living N- fixing bacteria that increasing Env. Biodiv. Soil Security Vol. 5 (2021) available nitrogen and consequently nutrient absorption by providing fixed nitrogen to plants as well as release certain chemical substances that enhance the availability of other nutrients for plants (El-Naqme et al., 2019 and Khan et al., 2019). Moreover, E. cloacae secretes organic acids which increase the solubility of phosphate and potassium (El- Mokadem and Sorour, 2014).

Regarding to nitrate content in potato tubers, Chicken manure + mixed strains gave decreasing in nitrate content compared with $100 \% \mathrm{NPK}$ application during two seasons respectively by (60.71 and $57.69 \%$ ). These results were in the same line with El-Sayed et al. (2014) and Zaki et al. (2019) on potato plant. On the other hand, SCG combined with biofertilizers gave tubers containing less nitrate by (57.14 and $53.85 \%$ ) compared by control. It was observed that organic potatoes contain significantly lower levels of 
nitrate than conventionally produced tubers (Table 7). In addition, biofertilizers inoculation proved to be very effective in increasing potato quality by reducing nitrate content compared to un-inoculated ones.

\section{Conclusion}

Combining organic manure (chicken manure at rate $24.7 \mathrm{~m}^{3} /$ ha.) with dual bacterial inoculation (Paenibacillus polymyxa as nitrogen fixer and Enterobacter cloacae as phosphate and potassium dissolving bacteria) as biofertilizers exhibited an enhancement in growth and potato productivity with best quality traits. This treatment also had a ppositive consequences on soil fertility. Therefore, it will be recommended a substitute to the use of classical fertilizers. On the other hand, combining spent coffee ground with biofertilizers gave improved results.

\section{Ethics approval and consent to participate}

This article does not contain any studies with human participants or animals performed by any of the authors.

\section{Conflict of interest}

There is no conflict between the authors of this study.

\section{Funding}

This research received no external funding

Consent for publication

All authors declare their consent for

TABLE 7. Influence of application various sources of organic fertilizers either solely or combined with biofertilizers ontuber quality of potato plants during the two seasons 2019-2020.

\begin{tabular}{|c|c|c|c|c|c|c|c|c|c|c|c|c|c|}
\hline \multirow{2}{*}{\multicolumn{2}{|c|}{ Treatments }} & \multicolumn{2}{|c|}{ N (\%) } & \multicolumn{2}{|c|}{ P (\%) } & \multicolumn{2}{|c|}{ K (\%) } & \multicolumn{2}{|c|}{ Protein (\%) } & \multicolumn{2}{|c|}{ Nitrate (\%) } & \multicolumn{2}{|c|}{$\begin{array}{c}\text { Total } \\
\text { carbohydrate } \\
(\%)\end{array}$} \\
\hline & & $1 \mathrm{st}$ & $2^{\text {nd }}$ & $1^{\mathrm{st}}$ & $2^{\text {nd }}$ & $1 \mathrm{st}$ & $2^{\text {nd }}$ & $1 \mathrm{st}$ & $2^{\text {nd }}$ & $1^{\text {st }}$ & $2^{\text {nd }}$ & $1 \mathrm{st}$ & $2^{\text {nd }}$ \\
\hline \multicolumn{2}{|c|}{$\begin{array}{c}\text { Control } \\
(100 \% \text { NPK) }\end{array}$} & 2.31 & 2.35 & 0.710 & 0.730 & 2.23 & 2.47 & 14.44 & 14.69 & 0.28 & 0.26 & 47.13 & 46.97 \\
\hline \multirow{5}{*}{ 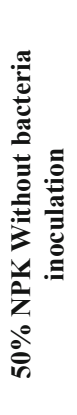 } & $\begin{array}{l}\text { Without } \\
\text { organic }\end{array}$ & 1.85 & 1.82 & 0.310 & 0.340 & 1.19 & 1.25 & 11.56 & 11.38 & 0.27 & 0.25 & 34.81 & 35.62 \\
\hline & FYM & 1.96 & 2.00 & 0.480 & 0.520 & 1.36 & 1.42 & 12.25 & 12.50 & 0.22 & 0.21 & 37.00 & 38.11 \\
\hline & Compost & 2.02 & 2.11 & 0.520 & 0.590 & 1.64 & 1.69 & 12.63 & 13.19 & 0.20 & 0.20 & 38.64 & 39.22 \\
\hline & $\begin{array}{l}\text { Chicken } \\
\text { manure }\end{array}$ & 2.14 & 2.24 & 0.570 & 0.660 & 1.96 & 1.81 & 13.38 & 14.00 & 0.17 & 0.16 & 41.51 & 42.36 \\
\hline & SCG & 2.03 & 2.19 & 0.520 & 0.610 & 1.78 & 1.75 & 12.69 & 13.69 & 0.18 & 0.17 & 39.18 & 39.86 \\
\hline \multirow{5}{*}{ 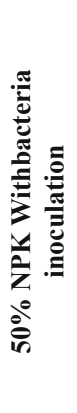 } & $\begin{array}{l}\text { Without } \\
\text { organic }\end{array}$ & 1.90 & 1.91 & 0.400 & 0.440 & 1.27 & 1.34 & 11.88 & 11.94 & 0.24 & 0.24 & 35.23 & 36.72 \\
\hline & FYM & 2.19 & 2.29 & 0.590 & 0.690 & 1.94 & 1.93 & 13.69 & 14.31 & 0.15 & 0.14 & 44.15 & 43.92 \\
\hline & Compost & 2.27 & 2.37 & 0.640 & 0.720 & 2.13 & 2.20 & 14.19 & 14.81 & 0.15 & 0.13 & 45.53 & 45.74 \\
\hline & $\begin{array}{l}\text { Chicken } \\
\text { manure }\end{array}$ & 2.38 & 2.43 & 0.750 & 0.810 & 2.32 & 2.71 & 14.88 & 15.19 & 0.11 & 0.11 & 48.80 & 49.13 \\
\hline & SCG & 2.30 & 2.37 & 0.700 & 0.740 & 2.26 & 2.55 & 14.38 & 14.81 & 0.12 & 0.12 & 47.00 & 46.81 \\
\hline \multicolumn{2}{|c|}{$\mathbf{L S D}_{\text {at } 5 \%}$} & 0.015 & 0.040 & 0.017 & 0.016 & 0.049 & 0.047 & 0.056 & 0.098 & 0.010 & 0.013 & 1.43 & 1.41 \\
\hline
\end{tabular}

FYM= Farmyard Manure, $\mathrm{SCG}=$ Spent Coffee Ground 
publication.

\section{Author contribution}

All authors of this study shared in all stages from the beginning with idea, design and experimental work up to interpretation of data

\section{References}

Abdel-Ati, Y.Y., Hammad, A.M.M. and Ali, M.Z.H. (1996). Nitrogen fixing and phosphate solubilizing bacteria as bio-fertilizers for potato plants under Minia condition. The First Egyptian -Hungarian Horticultural Conference. Sep. 15-17, Kafr ElSheikh, Egypt, 1: 25-34.

Abdeldaym, E. A., Traversa, A., Cocozza, C. and Brunetti, G. (2018). Effects of a 2-Year application of different residual biomasses on soil properties and potato yield. CLEAN-Soil, Air, Water, 46(12), $1-7$.

AbdEl-Nabi, H. M. E., El-Gamily, E. and Keshta, N. A. (2016). Response of potato plants to organic, bio and mineral fertilization. J. of Plant Production, 7(8), 861-867.

Abdel-Magid, H.M., R.K. Rabie, R.E.A. Sabrah and Abdel-Aal I. Sh, (1996). The interrelationship between microbial numbers, application rate and biodegradation in a sandy soil. Arab Gulf Journal Scient. Res., 14(3): 614-657

Abou-Hussein, S. D., El-Oksh, I., El-Shorbagy, T. and Gomaa, A. M. (2001). Effect of cattle manure, bio fertilizers and reducing mineral fertilizer on nutrient content and yield of potato plant.Egyptian Journal of Horticulture, 29(1): 99-116.

Abou-Zeid, M.Y. and Bakry, M.A.A. (2011). Integrated effect of bio-organic manures and mineral fertilizers on potato productivity and the fertility status of a calcareous soil. Australian Journal of Basic and Applied Sciences, 5(8):1385-1399.

Abdelhafez, A.A., Abbas, M.H.H., Attia, T.M.S., El Bably, W., Mahrous, S.E. (2018). Mineralization of organic carbon and nitrogen in semi-arid soils under organic and inorganic fertilization. Environmental Technology \&Innoviation 9: 243253. https://doi.org/10.1016/j. eti.2017.12.011

Al-Fraihat, A.H., Al-dalain, S.Y.A., AlRawashdeh, Z.B., Abu-Darwish, M.S. and Al-Tabbal, J.A. (2011). Effect of organic and biofertilizers on growth, herb yield and volatile oil of marjoram plant grown in Ajloregion, Jordan. J. Medicinal Plants Res., 5 (13): 2822- 2833.
Attar, Y. C., Mali, S. D. and Kamble, P. P. (2015) International journal of pure \&applied bioscience. Int. J. Pure App. Biosci, 3(1): 71-80.

Bakry, M. A., Paraas, M. M. and Abass, M. M. (2009). Effect of organic and inorganic soil amendments combined with mineral fertilizers on the fertility of calcareous soil and its productivity. Minufiya $J$. Agri. Res., 34: 2243-2260.

Rashwan, B.A., Ali, M. A. M. and Ferweez, H. (2018). Growth, yield, bulb quality and storability of garlic (Allium sativum L.) as affected by using poultry manure, sulphur and different levels of phosphorus fertilizer J. Soil Sci. and Agric. Eng., Mansoura Univ., 9 (10): 447 - 459.

Bhangoo, M. S., Day, K. S., Sudanagunta, V. R. and Petrucci, V. E. (1988). Application of poultry manure influences Thompson seedless grape production and soil properties. HortScience, 23(6): 1010-1012.

Baddour, A.G., Eman M.R. and El-Sharkawy, T.A. (2017). Effect of Organic Manure, Antioxidant and Proline on Corn (Zea mays L.) Grown under Saline Conditions. Environment, Biodiversity\& Soil Security, Vol.1, pp. 203- 217

Bora, T., Özaktan, H., Göre, E. and Aslan, E. M. E. K. (2004). Biological control of Fusariumoxysporum f. sp. melonis by wettable powder formulations of the two strains of Pseudomonasputida. Journal of Phytopathology, 152: 471-475.

Cervera-Mata, A., Navarro-Alarcón, M., Delgado, G., Pastoriza, S., Montilla-Gómez, J., Llopis, J. and Rufián-Henares, J. Á. (2019). Spent coffee grounds improve the nutritional value in elements of lettuce (Lactuca sativa L.) and are an ecological alternative to inorganic fertilizers. Food chemistry, 282: 1-8.

Cheng, C. F., \& Tsang, C. W. (1998). Simultaneous determination of nitrite, nitrate and ascorbic acid in canned vegetable juices by reversephase ion-interaction HPLC. Food Additives and Contaminants, 15(7), 753-758. http://dx.doi. org/10.1080/02652039809374706

Cockburn, M., Mills, P., Zhang, X., Zadnick, J., Goldberg, D., and Ritz, B. (2011). Prostate cancer and ambient pesticide exposure in agriculturally intensive areas in California. American journal of epidemiology, 173(11):1280-1288.

CoStat (2005). CoHortsoftware,version 6.3. 798 Lighthouse Ave. PMB 320 Monterey, CA, 93940, USA. 
Cruz, R., Cardoso, M. M., Fernandes, L., Oliveira, M., Mendes, E., Baptista, P. and Casal, S. (2012). Espresso coffee residues: A valuable source of unextracted compounds. Journal of agricultural and food chemistry, 60(32): 7777-7784.

DEFCO Manual (1974). Difco Manual of dehydrated culture media and reagent for microbial and laboratory producers 9 thedn.U.K.

Dikinya, O. and Mufwanzala, N. (2010). Chicken manure-enhanced soil fertility and productivity: Effects of application rates. Journal of Soil Science and Environmental Management, 1(3): 46-54.

Durzi, M. T. (2012). Effects of organic manure and bio-fertilizer application on flowering and some yield traits of coriander (Coriandrumsativum). Intl. J. Agri. Crop Sci., 4(3): 103 - 107.

Elbaalawy AM, Tantawy MF, El-Noamany NE (2020). Maximizing productivity of peanut (Arachis hypogaeaL.) plants in sandy soils using environmentally safe fertilizers. Environment Biodiversity \& Soil Security 4, 167- 179.

Elcossy, S.A.E., Abbas, M.H.H., Farid, I.M., Beheiry, G.Gh., Abou Youssef,M.F., Abbas,H.H., Abdelhafez, A.A., Mohamed, I. (2020) Dynamics of soil organic carbon in Typic Torripsamment soils irrigated with raw effluent sewage water. Environ Sci Pollut Res, 1-11. doi: 10.1007/s11356-019$\underline{07526-4}$

El-Mokadem, E.H. and Sorour, M. (2014). Effect of bio and chemical fertilizers on growth and flowering of Petunia hybrid plants. J. American Plant Physio.; 9(2): 68-77.

El-Naqme, K., El-Dissoky, R., Aiad, M. (2019). Impact of green manure, mineral and bio fertilizers on soil fertility, onion-maize productivity and N-use efficiency.Env. Biodiv. Soil Security, 3, 11-28.

El-Saied, R. M., Reham S. Abd Elhamed\&Hassanein, W.A. (2020). Possibility of decreasing consumption of chemical fertilizers with using phosphorous and potassium solubilizing bacteria inoculation on fennel. Plant Archives, 20(2): 3159-3169.

El-Sayed, S.F., Hassan, H.A., El-Mogy, M. M., AbdelWahab, A. (2014). Growth, yield and nutrient concentration of potato plants grown under organic and conventional fertilizer systems. AmericanEurasian Journal of Agricultural Environment Science, 14(7):636-643.

El-Sayed, A. A., El-Hanafy, S. H. and El-Ziat, R. A. (2015). Effect of chicken manure and humic acid on herb and essential oil production of Ocimum sp. Am Eurasian Journal of Agricultural Environment Science, 15: 367-379.

El-Shanshoury, A.R. (1995). Interaction of Azotobacter chroococcum, Azospirilium brasilens and Streptomyces mutabilis in relation to their effect on wheat. Journal of Agronomy and Crop Science., 175: $119-127$

Fayed, T.A., Hussein, A.M., Rashedy , A.A. and Elaksher, M.S. (2019). Effect of different types of organic fertilizers on the growth and productivity of peach cv 'Florida prince". Middle East Journal of Agriculture Research, 8(1): 347-355.

Gaballah, M.A. (1995). Effect of water logging and kinetin on the stability of leaf membranes, leaf osmotic potential, soluble carbon and nitrogen components and chlorophyll content of Ricinus communis plants. Phyton. Horn., 30: 199-208.

Gao, C., El-Sawah, A. M., Ali, D. F. I., Hamoud, Y. A., Shaghaleh, H. and Sheteiwy, M. S. (2020). The integration of bio and organic fertilizers improve plant growth, grain yield, quality and metabolism of hybrid maize (Zea mays L.). Agronomy, 10(3), 319-244.

Gomes, T., Pereira, J. A., Ramalhosa, E., Casal, S., Baptista, P. (2013). Effect of fresh and composted spent coffee grounds on lettuce growth, photosynthetic pigments and mineral composition. VII CongrIbéricoAgroingenieria y CienciasHortic., Pp1372-1376.

Hassan, F.A.S. and Ali, E.F. (2013). A comparative study between traditional mineral nutrition and other alternative sources on anise plant. Europe. J. Sci. Res., 106 (2): 201-212.

Hany M. A.,Darwesh R. D.(2020).Effect of Integrated Fertilization with Inorganic, Organic Fertilizers in Presence of Enterobacter ludwigii Local Strain on Growth, Yield and Fruit Quality of Anna Apple Trees.Environment, Biodiversity \& Soil Security, (4):345-360

Houlden, A., Timms-Wilson, T. M., Day, M. J. and Bailey, M. J. (2008). Influence of plant developmental stage on microbial community structure and activity in the rhizosphere of three field crops. FEMS microbiology ecology, 65(2): 193-201.

Hu, X.; Jishuang, C. and Jiangfeng, G. (2006). Two phosphate- and potassium-solubilizing bacteria isolated from Tianmu Mountain Zhejiang, China.

Env. Biodiv. Soil Security Vol. 5 (2021) 
J. World Microbio. and Biotech., 22 : 983-990

Jackson, M. L. (1958). Soil chemical analysis prentice Hall. Inc., Englewood Cliffs, NJ, 498, Pp 183-204.

Jambhulkar, P. P. and Sharma, P. (2014). Development of bioformulation and delivery system of Pseudomonas fluorescens against bacterial leaf blight of rice (Xanthomonas oryzaepv. oryzae). Journal of environmental biology, 35(5): 843.

Jones, J., Wolf, B.J.B. and Mills, H.A. (1991). A practical sampling, preparation, analysis, and interpretative guide. Plant analysis handbook, Micro-Macro Publishing, Athens.

Kannaiyan, S. (2002). Biofertilizers for sustainable crop production, In: Kannayan (ed) Biotechnology of Biofertilizers. Pp 9-49. Narosa Publication House, New Delhi.

Kantikowati, E., Yusdian, Y. and Suryani, C. (2019). Chicken manure and biofertilizer for increasing growth and yield of potato (Solanum tuberosum 1.) of Granola varieties. In IOP Conference Series: Earth and Environmental Science, 393 (1): 1-7.

Kasongo, R. K., Verdoodt, A., Kanyankagote, P., Baert, G. and Ranst, E. V. (2011). Coffee waste as an alternative fertilizer with soil improving properties for sandy soils in humid tropical environments. Soil use and Management, 27(1): 94-102.

Kaur, H., Gosal, S. K. and Walia, S. S. (2017). Synergistic effect of organic, inorganic and biofertilizers on soil microbial activities in rhizospheric soil of green pea. Annual Research \& Review in Biology, Pp 1-11.

Khan, A.,Singh, J., Upadhayay, V.K., Singh,A.V. and Shah,S. (2019). Microbial Biofortification: A green technology through plant growth promoting microorganisms. In sustainable green technologies for environmental management, Springer, Singapore, 255-269.

Khurana, P. S. M. and Naik, P. S. (2003). The Potato: an overview. the Potato Production and Utilization in Sub-tropics. Edited by SM Paul Khurana, JS Minas and SK Pandy Mehta Publication, New Delhi, 1-14.

Kondamudi, N., Mohapatra, S. K. and Misra, M. (2008). Spent coffee grounds as a versatile source of green energy. Journal of agricultural and food chemistry, 56(24):11757-11760.

Kumar, V. (2014). Characterization, bio-formulation development and shelf-life studies of locally isolated bio-fertilizer strains. Octa Journal of Environmental Research, 2(1): 32-37.

Lairon, D. (2009). Nutritional quality and safety of organic food a review. Agron Sustain Dev. 30(1): $33-41$.

Lin, Q.; Zhao, H. and Zhao, X. (2002 b). Rock phosphates solubilization of some microorganisms. Sci. Agri. Sinica, 35(10): 1232-1235.

Mandal, A., Patra, A. K., Singh, D., Swarup, A. and Masto, R. E. (2007). Effect of longterm application of manure and fertilizer on biological and biochemical activities in soil during crop development stages. Bioresource technology, 98(18): 3585-3592.

Mandic, L., Djukić, D., Beatovic, I., Jovovic, Z., Pesakovic, M. and Stevovic, V. (2011). Effect of different fertilizers on the microbial activity and productivity of soil under potato cultivation. African Journal of Biotechnology, 10(36): 6954-6960.

Mauricio, S., Claudia, M.R., Martin, A.P., Maria, L.C., Luigi, C. and Jose, A.C. (2009). Plant growth promoting properties of a strain of Enterobacter ludwigii isolated from Lolium perenne rhizosphere. Soil Biology andBiochemistry, 41: 1768-1774.

Mengel, K. and Kirkby, E.A. (1987). Principles of plant nutrition, 4th Edition. Inter. Potash Institute. Bern, Switzerland.

Metzner, H., Rau, H. and Senger, H. (1965). Unters uchungenzursynchronisierbarkeiteinzelnerpigme ntmangel-mutanten von Chlorella. Planta, 65(2): 186-194.

Mohammed, S.S. (2004). Assessment of the relative effectiveness for some organic materials conjucted with mineral nitrogen on soil fertility status, yield and quality of wheat grown on a newly cultivated soil. Egypt. J. Appl. Sci., 19(3): 298-310.

Mohamed, I., Bassouny, M.A., Abbas, M.H.H., Ming, Z., Cougui, C., Fahad, S., Saud, S., Khattab, Z. K., Ali, S., Salem, H.M., Azab, A., Ali, M. (2021). Rice straw application with different water regimes stimulate enzymes activity and improve aggregates and their organic carbon contents in a paddy soil. Chemosphere 274, 129971. https://doi. org/10.1016/j.chemosphere.2021.129971

Mussatto, S. I., Carneiro, L. M., Silva, J. P., Roberto, I. C. and Teixeira, J. A. (2011). A study on chemical constituents and sugars extraction from spent coffee grounds. Carbohydrate polymers, 83(2): 368-374. 
Nandakumar R. R., R., Kandan, A., Suresh, S., Bharathi, M., Raguchander, T. and Samiyappan, R. (2002). Pseudomonas fluorescens based bio-formulation for the management of sheath blight disease and leaf folder insect in rice. Crop Protection, 21(8): 671-677.

Nautiyal, C.S. (1999). An efficient microbiological growth medium for screening phosphatesolubilizing microorganisms. FEMS Microbiol. Lett., 170: 265-270.

Park, M., Singvilay, O., Seok, Y., Chung, J. and Ahn, K. (2003). Effect of phosphate solubilizing fungi on P uptake and growth to tobacco in rock phosphate applied soil. Korean J. Soil Sci. Fertil., 36: 233-238.

Peters, I.S.,Combs, B. ,Hoskins, I. , Iarman, I., Kover Watson, M. and Wolf, N. (2003). Recommended methods of manure analysis. Univ. Wisconsin, Cooperative extension Publ., Madison.

Premsekhar, M. and Rajashree, V. (2009). Influence of bio-fertilizers on the growth characters, yield attributes, yield and quality of tomato. AmericanEurasian J. Sustainable Agric., 3(1): 68-70.

Rahimi, A., Siavash, M.S., Ghiyasi, M., Heydarzadeh, S., Ghazizadeh, K. and Popović-Djordjević, J. (2019). The Influence of chemical, organic and biological fertilizers on agrobiological and antioxidant properties of Syrian cephalaria (CephalariaSyriacaL.). Agriculture, 9(6): 122135.

Ranganna, S. (1977). Manual of analysis of fruit and vegetable products central food. Technological Research Institute Mysore, USA.

Richards, L. A. (1954). Diagnosis and Improvement of. Saline and Alkali Soils. Handbook, 60.

Sadasivam, S. and Manickam, A. (1996). Biochemical methods. second edition, Newage international. India

Saleh, E. A., Nokhal, T. H., El-Borollosy, M. A., Frendrik, I., Sharaf, M. S. and El-Sawy, M. (1998). Effectiveness of dual inoculation with diazotrophs and vesicular arbuscular mycorrhizae on growth and medicinal compounds of Datura stramonium. Arab Universities Journal of Agricultural Science, 6: 343-355.

Shaaban, L.D., Hassanien, W.A. and El-saied, R.M. (2015). Role of phosphate and potassium solubilizing bacteria on physiological changes and yield parameters of Vigna unguiculataL. Egypt J.
Bot., (1) 37-52.

Shehata, S. A., Abouziena, H. F., Abdelgawad, K. F. and Elkhawaga, F. A. (2019). Weed control efficacy, growth and yield of potato (Solanum tuberosum L.) as affected by alternative weed control methods. Potato Research, 62(2): 139-155.

Sheng, X.F. and Huang W.Y. (2001). Physiological characteristics of strain NBT of silicate bacterium. Acta Pedol. Sin., 38:569-574.

Singh, S.K., Sharma, M., Reddy, K. R. and Venkatesh, T. (2018). Integrated application of boron andsulphur to improve quality andeconomic yield in potato. Journal of Environmental Biology,3 9:204-210

Sivakumar, G., Josephrajkumar, A. and Rangeshwaran, R. (2012). Bioefficacy of peat formulation of bacterial antagonists on growth promotion and disease suppression in cardamom (Elettaria cardamomumMaton). Journal of Biological Control, 26(3): 255-259.

Stylianou, M., Agapiou, A., Omirou, M., Vyrides, I., Ioannides, I. M., Maratheftis, G. and Fasoula, D. (2018). Converting environmental risks to benefits by using spent coffee grounds (SCG) as a valuable resource. Environmental Science and Pollution Research, 25(36): 35776-35790.

Walker, B., Kinzig, A. and Langridge, J. (1999). Plant attributes diversity, resilience and ecosystem function: the nature and significance of dominant and minor species. J. Ecosystems, 2(2): 95-113.

Widowati, L. R., Sri, W., Zainuddin, U. and Hartatik, W. (2005) Effect of organic fertilizer compost enriched with mineral materials and biological fertilizer on the properties of soil, nutrient uptake and organic vegetable production. Research Project Report Agribusiness Development Program, Soil Research Institute.

Widowati, T., Nuriyanah and Sukiman, $H$. (2019). Production of indole acetic acid by Enterobactercloacea H3 isolated from Mungbean (Vigna radiata) and its potential supporting the growth of soybean seedling. In IOP Conference Series: Earth and Environmental Science, 308(1): 1-6.

Yamane, K., Kono, M., Fukunaga, T., Iwai, K., Sekine, R., Watanabe, Y. and Iijima, M. (2014). Field evaluation of coffee grounds application for crop growth enhancement, weed control, and soil improvement. Plant Production Science, 17(1):

Env. Biodiv. Soil Security Vol. 5 (2021) 
93-102.

Zaki, A., Fahmy M.H., Galal, Y.G.M. and Abd ElHameed,A.H. (2021). Importance of Bio-Organic Fertilizers on Peanut (Arachis Hypogaea L.) Nutrition Following Organic Farming Approach with Application of ${ }^{15} \mathrm{~N}$ Isotope Dilution Concept. Environment, Biodiversity\&Soil Security, Vol. 5, pp. $15-29$

Zaki, M. E., Mohamed M.H.M. and Halwa S.S.(2019). Impact of agricultural treatments on production and quality of potato tubers. Journal of Horticultural Science \& Ornamental Plants 11 (3): 232-243.

Zhong, W., Gu, T., Wang, W., Zhang, B., Lin, X., Huang, Q. and Shen, W. (2010). The effects of mineral fertilizer and organic manure on soil microbial community and diversity. Plant and soil, 326(1-2): 511-522. 